\title{
Manajemen Strategis Pendayagunaan Zakat Infak dan Shadaqah dalam Pengentasan Kemiskinan
}

\author{
Agum Restu Alam ${ }^{1 *}$, Saeful Anwar ${ }^{2}$, Asep Iwan Setiawan ${ }^{1}$ \\ ${ }^{1} J u r u s a n$ Manajemen Dakwah, Fakultas Dakwah dan Komunikasi, \\ UIN Sunan Gunung Djati, Bandung \\ ${ }^{2} J u r u s a n$ PengembanganiMasyarakat Islam, Fakultas Dakwah dan Komunikasi, \\ UIN Sunan GunungiDjati, Bandung \\ *Email:Agumrestualam@gmail.com
}

\begin{abstract}
ABSTRAK
Tujuan dari penelitian ini untuk mengetahui bagaimana keberhasilan MAI dalam mengentaskan kemiskinan melalui program bina dengan pendayagunaan zakat, infak dan shadaqah yang produktif serta tahapan Manajemen Strategis yang ada di MAI. Penelitian ini menggunakan metode deskriptif dengan pendekatan kualitatif, dengan teknik pengumpulan data yang dihimpun melalui teknik observasi, wawancara, studi dokumen dan studi pustaka. Hasil penelitian menunjukan bahwa proses pendayagunaan MAI pada tahapan Analisis Lingkungan telah dilakukan untuk memaksimalkan kekuatan dan memanfaatkan peluang yang ada sehingga dapat meminimalisir kelemahan dan ancaman sehingga proses pendayagunaan dapat mengentaskan kemiskinan. Tahapan Formulasi Strategi berupa perumusan visi, tujuan, strategi, dan kebijakan telah diprogram secara sistematis. Selanjutnya Implementasi Strategi dengan membuat lima program utama yang dibuat secara matang dan profesional. Terakhir tahapan Evaluasi dan Pengendalian Strategi dengan melakukan evaluasi secara berkala dan sistematis sehingga pengendalian program dapat dilakukan dengan baik sesuai prosedur.
\end{abstract}

Kata Kunci: Manajemen Strategis; Pendayagunaan; Zakat; Kemiskinan.

\section{ABSTRACT}

The purpose of this study is to find out how the success of MAI in alleviating poverty through community development programs by utilizing productive zakat, infaq and shadaqah as well as the stages of Strategic Management in MAI. The method used is a descriptive method with a qualitative approach, with data collection techniques collected through observation, interviens, document studies and literature studies. The results showed that the process of utilizing the MAI at the Environmental Analysis stage had been carried out to maximize strengths and take advantage of existing opportunities so as to minimize weaknesses and threats so that the empowerment process could reduce poverty. The Stages of Strategy Formulation in the form of 
A. R. Alam, S. Anwar, A. I. Setiawan

vision, goals, strategies and policies have been systematically programmed. Next Implementation Strategy by making five main programs that are made in a mature and professional manner. The last step is the Evaluation and Control Strategy by conducting periodic and systematic evaluations so that program control can be carried out properly according to procedures.

Keywords: Strategic Management; Utilization; Alms; Poverty.

\section{PENDAHULUAN}

Fenomena kemiskinan di Indonesia semakin kompleks, dimana data menunjukan menurut Badan Pusat Statistik (BPS) pada tahun 2018 jumlah populasi di Indonesia berjumlah 265,015.3 Ribu Jiwa atau 265 Juta Jiwa dan persentase penduduk miskin pada tahun 2018 sebesar 9,82\%. Dengan data tersebut, maka tugas kita bersama untuk menurunkan angka kemiskinan tersebut. Dengan jumlah umat Islam di Indonesia yang begitu besar, sebagaimana di lansir oleh Kementrian Agama Indonesia pada tahun 2016 jumlah penduduk Indonesia yang beragama Islam sebesar 207.176.162 atau $87,21 \%$. Dengan jumlah penduduk muslim yang sangat besar bahkan menjadi mayoritas penduduk yang mengisi bangsa dan negara ini seyogyanya harus segera berbenah akan identitas muslim itu sendiri. Sistem ekonomi Islam yang menjadi pilar seyogyanya menjadi solusi, zakat hadir untuk mengupayakan agar salah satu ashnaf ini segera bisa tertangani.

Zakat merupakan bagian instrumental dan fundamental dalam lima pilar rukun Islam. Posisinya yang berada di tengah-tengah menjadi penyeimbang horizontal dan vertikal kehidupan manusia. Salah satu bagian instrumental yang strategis dalam proses pengentasan kemiskinan dan memiliki pengaruh terhadap tingkah laku, pola dan cara berfikir ekonomi masyarakat agar zakat tidak hanya menjadi distribusi konsumtif, namun agar berdaya dan produktif.

Dari sisi pembangunan kesejahteraan umat, zakat pun memiliki peran pemerataan pendapatan. Dengan catatan, apabila zakat dikelola dengan baik maka akan memberikan efek positif bagi pertumbuhan ekonomi dan sekaligus pemerataan pendapatan, economic growth with equality (Hafidhuddin, 2007:71).

Dana Zakat, Infak, dan Shadaqah tidak akan optimal jika tidak dikelola dengan baik dan sistematis. Karena kita hidup di zaman milenial yang dimana segala sesuatu harus di kelola secara sistematis. Pengelolaan dana zakat, infak, shadaqah telah di atur secara hukum oleh UU RI No. 23 tahun 2011 yang merupakan penyempurnaan dari UU RI No. 38 Tahun 1999, yang dimana harus adanya sebuah lembaga yang mengelola dana umat secara baik dan profesional.

Dengan adanya pengelolaan lembaga zakat secara profesional maka akan berdampak baik pada tujuan pengentasan kemiskinan itu sendri mengingat di era informasi atau digital ini masyarakat diharapkan lebih mengetahui, paham dan mengamalkan kewajiban berzakat, meskipun masih ada kendala di sebagian

Tadbir: Jurnal Manajemen Dakwah Vol. 4 No. 4 (2019) 363-386 
Manajemen Strategis Pendayagunaan Zakat Infak dan Shadaqah dalam Pengentasan Kemiskinan kalangan masyarakat lembaga zakat. Sehingga agar adanya timbal balik yang baik antar lembaga dengan masyarakat maka harus adanya interaksi yang lebih intens dengan lembaga.

Dengan situasi seperti ini, maka seluruh Organisasi Pengelola Zakat (OPZ) telah melakukan pembenahan internal, serta terbetuknya intelligent organization. Sebuah organisasi tidak dapat survive dan memungkinkan mengalami kegagalan karena menghadapi discontinuous change, apabila tidak segera memperbaharui referensinya dan terjebak dalam sumber-sumber yang tidak update (Anwar, 2016: 250).

Dalam Gerakan dakwah saat ini pula, Gerakan zakat dan da'i harus sinergis mengingat peran da'i dalam pendayagunaan zakat sangat penting berbanding lurus pada media-media yang berimplikasi positif pada peningkatan keagamaan yang semakin komprehensif yang dimana meningkatkan produktivitas umat dalam mengentaskan kemiskinan itu sendiri (Setiawan, 2012: 348).

Terlepas daripada itu, adanya tujuan konsumtif dan produktif dalam proses pengentasan kemiskinan yang dilakukan oleh lembaga zakat. Meskipun tujuan konsumtif atau charity. masih menjadi kegiatan utama kebanyakan lembaga zakat. Tujuan zakat tidak hanya ada dalam lingkup menyantuni orang miskin secara konsumtif, tetapi memiliki tujuan yang lebih permanen yaitu mengentaskan kemiskinan.

Oleh karena itu, pengelolaan distribusi zakat yang produktif menjadi fokus yang utama seluruh lembaga zakat, dimana saat ini perkembangan metode serta sistem distribusi zakat yang mengalami perkembangan sangat pesat baik secara kajian objek ilmiah serta penerapannya di berbagai lembaga amil zakat yaitu metode pendayagunaan produktif. Zakat produktif adalah modal yang diberikan kepada mustahik dengan tujuan agar mustahik tersebut menjalankan suatu kegiatan ekonomi atau lainnya dalam bentuk usaha, agar taraf ekonomi dan potensi mustahik lebih produktif berkembang.

Sehubungan dengan hal itu, maka dana zakat maupun infak dan shadaqah dapat menjadi solusi yang berfungsi sebagai salah satu dana sosial-ekonomi bagi umat Islam dan masyarakat pada umumnya. Dalam hal ini, proses pendayagunaan yang masih harus dijalankan secara profesional yang dikelola oleh lembaga amil zakat yang dimana tidak terbatas pada kegiatan-kegiatan konsumtif saja, tetapi dapat pula berfungsi sebagai dana penyokong kegiatankegiatan ekonomi umat, seperti halnya dalam program pengetasan kemiskinan dan pengangguran dengan memberdayakan zakat produktif kepada mereka yang memerlukan sebagai modal usaha.

Dana zakat, infak, dan shadaqah akan berperan sebagai pendukung dan penyokong peningkatan taraf ekonomi para mustahik apabila difungsikan secara produktif dengan kegiatan-kegiatan yang produktif pula. Pendayagunaan zakat 
produktif sesungguhnya mempunyai konsep dasar dalam ruang lingkup perencanaan dan pelaksanaan yang cermat dan tepat seperti mengkaji penyebab kemiskinan, tidak adanya modal untuk membuka usaha, dan kekurangan lapangan kerja, dengan adanya masalah tersebut maka perlu adanya proses dan tahap-tahap dari hulu ke hilir dalam upaya mengembangkan dan memberdayakan dana zakat, infak, dan shadaqah yang produktif tersebut.

Berangkat dari latar belakang tersebut maka peneliti membatasi wilayah pembahasan permasalahan kepada Manajemen Strategis Pendayagunaan Zakat Infak dan Shadaqah Mandiri Amal Insani Foundation Region VI Jawa Barat dalam Pengentasan Kemiskinan. Lembaga Mandiri Amal Insani Foundation Region VI terletak di Jalan Soekarno Hatta No.486 Kelurahan Batununggal Kecamatan Bandung Kidul Bandung 40266.

Berdasarkan dari latar belakang tersebut, maka peneliti membuat rumusan masalah yaitu: (1) Bagaimana proses Analisis Lingkungan di Mandiri Amal Insani Foundation Region VI Jawa Barat? (2) Bagaimana Formulasi Strategi Pendayagunaan Zakat, Infak, Shadaqah di Mandiri Amal Insani Foundation Region VI Jawa Barat dalam Pengentasan Kemiskinan? (3) Bagaimana Implementasi Strategi Pendayagunaan Zakat, Infak, Shadaqah di Mandiri Amal Insani Foundation Region VI Jawa Barat dalam Pengentasan Kemiskinan? (4) Bagaimana evaluasi dan pengendalian strategi pendayagunaan zakat, infak, shadaqah di Mandiri Amal Insani Foundation Region VI Jawa Barat dalam pengentasan kemiskinan?

Tujuan Penelitian meliputi: (1) Untuk mengetahui analisis lingkungan di Mandiri Amal Insani Foundation Region VI Jawa Barat dalam pengentasan kemiskinan, (2) Untuk mengetahui formulasi strategi pendayagunaan zakat, infak, shadaqah di Mandiri Amal Insani Foundation Region VI Jawa Barat dalam pengentasan kemiskinan, (3) Untuk mengetahui implementasi strategi pendayagunaan zakat, infak, shadaqah di Mandiri Amal Insani Foundation Region VI Jawa Barat dalam pengentasan kemiskinan, (4) Untuk mengetahui evaluasi dan pengendalian strategi pendayagunaan zakat, infak, shadaqah di Mandiri Amal Insani Foundation Region VI Jawa Barat dalam pengentasan kemiskinan.

Metode yang digunakan yaitu dengan metode deskriptif serta pendekatan kualitatif. Adapun teknik pengumpulan data peneliti menggunakan observasi dan wawancara secara mendalam dengan para narasumber berikut Ketua Divisi Pendayagunaan sebagai data primer. Sedangkan data sekunder menggunakan kajian pustaka mengenai pendayagunaan zakat, infak, dan shadaqah. Data dari hasil analisis penelitian kemudian di hasilkan sebuah kesimpulan. 


\section{LANDASAN TEORITIS}

Hal yang harus dilakukan dalam upaya memecahkan masalah dan mencapai tujuan sebagaimana yang ingin dicapai, perlu dilakukan studi pustaka atau literatur guna mendukung hasil penelitian agar didapat hasil yang maksimal sebagaimana yang telah diharapkan. Adapun literaturnya yaitu: Manajemen Strategis, Zakat Infak dan Shadaqah serta studi pembahasan kesejahteraan masyarakat (fenomena) kemiskinan.

Manajemen strategis adalah kerangka dalam rangkaian keputusan dan eksekusi suatu manajerial yang menentukan sebuah kinerja perusahaan atau organisasi dalam kurun waktu yang panjang. Manajemen strategisimemfokuskan pada proses pengamatan serta evaluasi peluang dan ancaman lingkungan dengan melihat kekuatan dan kelemahan perusahaan atau organisasi. Manajemen strategis terdiri dari pengamatan atau analisis lingkungan serta perumusan strategi (formulasi), implementasi strategi, dan evaluasi serta pengendalian (Wheelen, 2003: 4).

Manajemen strategik merupakan arus keputusan dan eksekusi yang mengarah pada perkembangan suatu strategik atau strategik-strategik yang efektif untuk membantu mencapai sasaran perusahaan atau organisasi. Proses manajemen strategik ialah suatu cara dengan jalan bagaimana para perencana strategik menentukan sasaran untuk membuat kesimpulan strategik.

Definisi manajemen strategik yaitu suatu pilihan alternatif strategik yang terbaik bagi organisasi dalam berbagai hal dalam rangka mendukung gerak usaha perusahaan atau organisasi. Oleh karena itu, sebuah organisasi atau perusahaan seyogyanya melaksanakan manajemen strategik secara berkesinambungan konsisten serta fleksibel berdasarkan kondisi di lapangan. Dalam pengertian (definisi) manajemen strategis menurut beberapa ahli tersebut, penulis dapat mengambil kesimpulan bahwa manajemen strategis adalah sebuah analisis sistem organisasi yang mendalam serta bersifat holistik melalui tahapan-tahapan yang sistematis dalam rangka untuk mencapai tujuan suatu organisasi.

Menurut Wheelen dan Hunger (2004: 11) dalam Solihin (2012: 78), modelimanajemen strategisiterdiri dari empat tahap proses yaitu, Environmental Scanning (Analisis Strategi), Strategy Formulation (Formulasi Strategi), Strategy Implementation (Implementasi Strategi) dan Evaluation and Control (Evaluasi dan Pengendalian). 


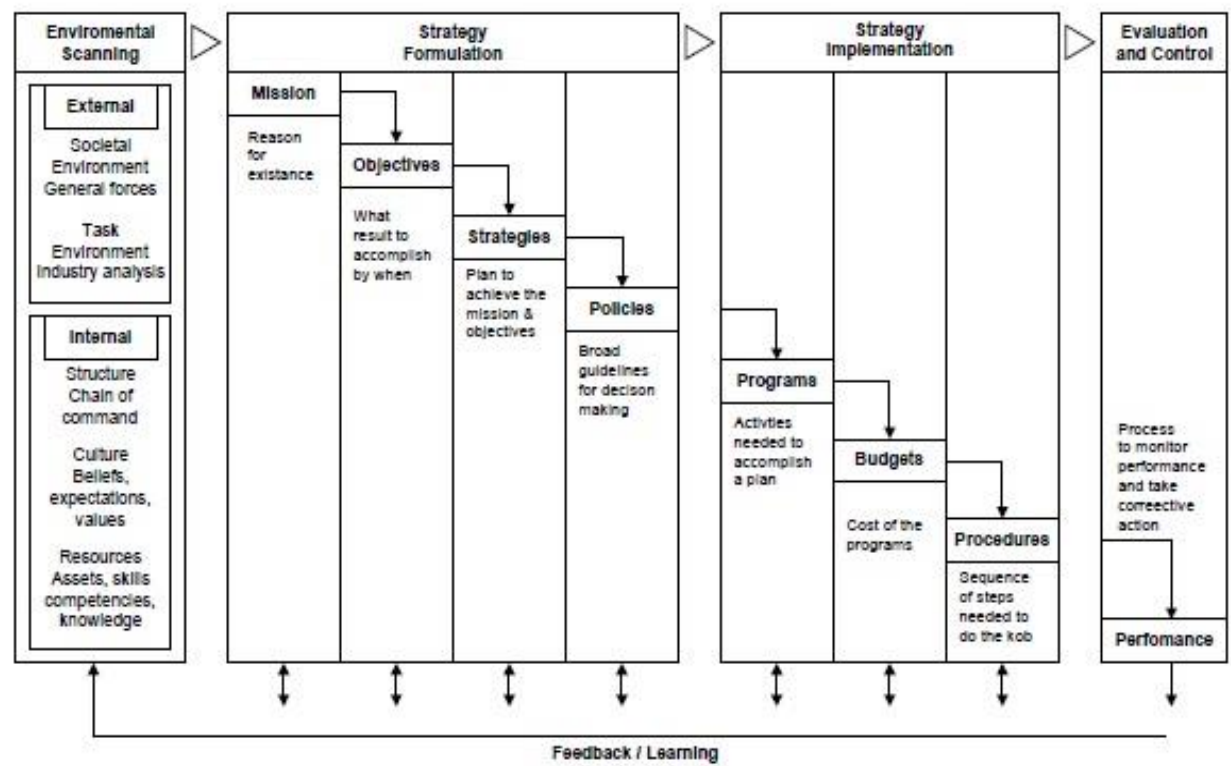

Sumber: Dikutip dari Thomas R. Wheelen dan J. David Hunger, Manajemen Strategis, 2003

Gambar 1. Model Manajemen Strategis Wheelen dan Hunger

Tahap pertama yaitu Analisis Lingkungan, analisis lingkungan (environmental scanning) yaitu suatu proses pemantauan (monitoring), pengevaluasian serta penyebaran informasi yang berasal dari lingkungan internal atau eksternal perusahaan kepada personal kunci (key people) di dalam sebuah organisasi. Kegiatan ini atas proses analisis atau pemindaian lingkungan terhadap lingkungan eksternal organisasi yang dikelompokan oleh Wheelen dan Hunger sebagai societal environment dan task environment.

Tahap kedua yaitu Formulasi Strategi, Formulasi strategi adalah perencanaan jangka panjang yang mencakup proses pengembangan misi, tujuan, strategi dan kebijakan perusahaan atau organisasi. Formulasi strategi memiliki tahapan yang dimulai dengan kegiatan analisis situasional (situasional analysis) yaitu suatu proses untuk menemukan kecocokan strategis (strategic fit) antara peluang yang ada dilingkungan eksternal perusahaan dengan kekuatan internal yang dimiliki perusahaan atau organisasi pada saat yang sama memperhitungkan berbagai kencaman yang ada dilingkungan luar perusahaan dan kelemahan internal perusahaan atau sebuah organisasi.

Tahap ketiga setelah perumusan startegi adalah pelaksanaan strategi. Pelaksanaan strategi adalah sebuah realisasi dari strategi yang telah dipilih. Strategi yang dipilih seyogyanya di jalankan dengan konsisten, dan untuk itu perlu dibangun suatu struktur organisasi yang cocok, program kerja yang jelas, 
Manajemen Strategis Pendayagunaan Zakat Infak dan Shadaqah dalam Pengentasan Kemiskinan anggaran yang memadai, sistem yang jelas dan kemampuan para pengelolanya. Tujuan dan strategi organisasi yang telah dirancang akan dapat diimplementasikan dengan baik apabila tujuan dan strategi tersebut dituangkan ke dalam rangkaian kegiatan dalam bentuk program. Penerapan strategi sering kali disebut "tahap aksi" dari manajemen strategis. Menerapkan strategi berarti memobilisasi karyawan dan manajer untuk melaksanakanpstrategi yang telah dirumuskan.

Tahap terakhir yaitu evaluasi dan pengendalian strategi, yaitu evaluasi strategik adalah tahapan proses memperoleh informasi mengenai pelaksanaan rencana-rencana bisnis dan kinerjanya serta mengkomparasikan informasi tersebut dengan standar sesuai prosedur. Proses evaluasi dan control strategi dimulai dari menentukan apa yang harus diukur, menetapkan standar kinerja, melakukan pengukuran, dan apabila tidak sesuai dengan harapan maka harus dilakukan tindakan mengoreksi.

Dalam proses ini tidak hanya sebagai cara dalam mencapai suatu tujuan namun melainkan meliputi pula penentuan berbagai tujuan organisasi dengan menetapkan tujuan jangka panjang dan pengalokasian sumber daya yang dibutuhkan dan memperhatikan segala kemungkinan yang terjadi dan mempersiapkan segala potensi yang ada (Latifah, 2017: 10).

Peneliti menyimpulkan bahwa dari pengertian evaluasi di atas yaitu tahapan akhir dari proses manajemen strategis adalah evaluasi yang mencakup aspek penilaian kinerja yang berlanjut dengan berjalannya umpan balik, yang akan menjadi rekomendasi masukan bagi perbaikan atau penyempurnaan strategi dalam pengimplemetasian program selanjutnya serta mengontrol hasil evaluasi agar menjadi sebuah rujukan, dan perbaikan pada masa yang akan datang.

Kata pendayagunaan terdiri dari dua kata, yaitu daya yang artinya kekuatan, tenaga, cara, dan guna, yang artinya faedah, manfaat. Maka dari itu, pendayagunaan yakni proses, cara, untuk memanfaatkan, Sehingga pendayagunaan zakat dapat diartikan sebagai suatu proses untuk memanfaatkan zakat agar lebih berhasil guna untuk masyarakat terutama masyarakat dalam kelompok penerima zakat.

Pendayagunaan adalah suatu proses bagaimana cara atau usaha dalam mewujudkan hasil dan manfaat yang lebih besar dan lebih baik. Adapun pola pendayagunaan dana zakat merupakan bentuk proses optimalisasi serta efisiensi hasil pendayagunaan dana zakat agar lebih efektif, bermanfaat dan berdayaguna.

Menurut Qardhawy (1996: 34) Zakat dari kata az-zakah, dari segi bahasa merupakan kata dasar (masdar) dari kata zaka yang berarti tumbuh, bersih, dan berkembang dan berkah. Sedangkan menurut istilah literatur fiqh adalah proses penyerahan sejumlah harta tertentu yang diwajibkan Allah kepada orang-orang yang berhak menerimanya. Definisi zakat yang dikemukakan ulama fikih kebanyakan mengkonsentrasikan kepada pengertian zakat maal (kekayaan) saja 
dan tidak mencakup pengertian zakat fitrah, kecuali Mazhab Syafi'i.

Infaq berasal dari kata anfaqa yang memiliki arti 'mengeluarkan sesuatu (harta) untuk kepentingan sesuatu. Sedangkan menurut terminologi syariat atau istilah fiqh, infak diartikan sebagai proses mengeluarkan sebagian dari harta atau pendapatan penghasilan untuk suatu kepentingan yang diperintahkan ajaran Islam.

Shadaqah berasal dari kata shadaqa yang berarti yang berarti benar. Hukum melaksanakan infaq dan shodaqoh adalah sunnah. Menurut terminologi syariat, shadaqah sama dengan pengertian infak, dari segi pengertian, hukum dan ketentuan-ketentuannya. Hanya saja, jika infak berkaitan dengan materi, shadaqah memiliki arti lebih luas menyangkut hal yang bersifat nonmaterial, seperti memberikan jasa, mengajarkan ilmu pengetahuan, dan mendoakan orang lain.

Secara harfiah menurut Poerwadarmita (dalam Bambang Rustanto, 2015: 1), kemiskinan berasal dari kata dasar miskin yang atinya "tidak berharta-benda". Dalam pengertian yang lebih komprehensif, kemiskinan dapat dikonotasikan sebagai sebuah kondisi ketidakberdayaan atau ketidakmampuan baik secara indivdu, kelompok, maupun keluarga sehingga kondisi ini rentan terhadap timbulnya permasalahan sosial lainnya.

Menurut Kuncoro (1997), mendefinisikan kemiskinan sebagai ketidakberdayaan dalam upaya memenuhi kebutuhan standar hidup minimum. Sedangkan Kartasasmita (1997) berpendapat bahwa kemiskinan adalah masalah dalam proses pembangunan yang bercirikan atau ditandai dengan adanya pengangguran dan keterbelakangan dalam kurun waktu tertentu meningkat menjadi sebuah ketimpangan.

Budaya kemiskinan menurut para ahli sebenarnya bukanlah faktor utama adanya kemiskinan, melainkan diakibatkan oleh sistem sosial. Mereka miskin karena sifak kemalasan mereka dibiarkan serta tidak mau menabung. Fenomena tersebut mungkin hanya dimiliki oleh sebagian orang miskin saja karena keterbatasan mereka dalam mengakses suatu sumber mata pencaharian (Hilman, 2016: 344).

Berbagai pengertian (definisi) serta penjelasan yang telah dipaparkan diatas dengan demikian dideskripsikan bahwa fenomena atau peristiwa kemiskinan yang terjadi di Indonesia dapat menjabarkan sebagai suatu kondisi ketidakmampuan dan ketidakberdayaan yang alami maupun dinamika sosial secara individual, komunal (kelompok, komunitas), dan keluarga untuk memenuhi kebutuhan dasar hidup minimum.

\section{HASIL DAN PEMBAHASAN}

Mandiri Amal Insani Foundation merupakan lembaga organisasi nirlaba (non profit) yang bergerak dalam kegiatan penghimpunan, pengelolaan, 
Manajemen Strategis Pendayagunaan Zakat Infak dan Shadaqah dalam Pengentasan Kemiskinan pendistribusian dana Zakat, Infaq, Shadaqah serta dana sosial lainnya yang halal dan legal dari muzakki secara individual maupun komunal. Mandiri Amal Insani Foundation berdiri pada tanggal 2 oktober 2014, dengan landasan hukum yuridis dan terdaftar secara legal sebagai Badan Hukum Nasional sesuai Keputusan Menteri Hukum dan Hak Asasi Manusia dengan berdasarkan Surat Keputusan Nomor AHU-07192.50.10.2014 pada tanggal 6 oktober 2014. Didirikan oleh segenap perintis yang dimana merupakan orang-orang mandiri itu sendiri karena melihat potensi yang ada sebagai bagian dari Mandiri Group dengan semangat dan tekad LAZ yang Modern, Terpercaya, dan Rahmatan Lil A'lamin.

Dalam proses berdirinya MAI Foundation, yang melatar belakangi lahirnya Mandiri Amal Insani Foundation tidak lepas dari sebuah dinamika yang terjadi di dalam Internal kepengurusan Mandiri itu sendiri. Secara tidak langsung, MAI Foundation merupakan sebuah Yayasan yang ada di dalam naungan Mandiri Group. Di awali dari semangat sebuah kajian keislaman yang dipelopori oleh orang-orang internal Mandiri itu sendiri yang aktif dan progresif menjadi sebuah badan yang lebih sistematis dengan nama sebutan BAPEKIS (Badan Pembinaan Kerohanian Islam), bisa dikatakan bahwa BAPEKIS ini adalah ektrakulikuler para karyawan-karyawan mandiri yang beragama muslim dalam upaya memenuhi aspek dakwah serta asupan kerohanian secara khusus dilingkungan Mandiri.

BAPEKIS memiliki turunan atau cabang kegiatan lain yaitu BPZIS (Badan Pengelolaan Zakat, Infaq, dan Shadaqoh) yang dimana BPZIS ini berfungsi sebagai wadah penghimpunan dana zakat, infaq, dan shadaqoh dengan ruang lingkup para karyawan Mandiri Grup. Dalam perjalannya, BPZIS lahir pada tahun 2005. Sebagaimana telah dipaparkan oleh bapak R. Widad Mu'tashim S. Ab selaku General Support dan PLT Manager MAI Jabar Region VI menyatakan bahwa:

"Jauh sebelum berdirinya MAI, dahulunya lembaga ini hanya sebagai hasil bagian ekstrakulikuler para karyawan Mandiri yang merupakan turunan dari kajian sebuah komunitas atau ektrakulikuler para karyawan khusus muslim yang dinamakan BPKIS (Badan Pembinaan Kerohanian Islam). Dengan semangat keislaman yang ingin terus tumbuh melalui BPKIS yang ada sejak tahun 2000-an, seiring berjalannya waktu dan melihat potensi yang ada maka mereka mendirikan BPZIS (Badan Pengelolaan Zakat Infak Shadaqah) dengan izin dan kerjasama bersama BAZNAS karena BPZIS yang sifatnya Badan Pengumpul Dana ZIS namun untuk tahap proses bisnis lainnya seperti pengelolaan, penyaluran dan pelaporan hanya dapat dilakukan (berwenang) oleh Baznas itu sendiri”. (Hasil Wawancara bersama General Support dan PLT Manager R. Widad Mu'tashim, S. Ab, dilaksanakan pada tanggal 10 Juli 2019).

Setelah melakukan penelitian di Mandiri Amal Insani Foundation Region VI Jawa Barat dengan melalui berbagai langkah penelitian, mulai dari observasi ke lapangan secara langsung, kemudian melakukan wawancara dengan Support 
Manajer (PLT Manajer Refion VI), bagian penyaluran (program) serta beberapa mustahik, maka penulis dapat mengetahui bahwa teori manajemen strategik telah diterapkan oleh mandiri Amal Insani Foundation Region VI Jawa Barat. Hal tersebut karena indikator yang ada dalam manajemen strategik mulai dari analisis lingkungan, formulasi strategi, implementasi strategi, serta evaluasi dan pengendalian strategi semuanya sudah sesuai dengan teori Wheleen dan Hunger dalam bukunya Manajemen Strategis.

Manajemen strategis adalah kerangka dalam rangkaian keputusan serta eksekusi sistem manajerial yang memberikan kepastian kinerja perusahaan atau organisasi dalam kurun waktu yang panjang. Manajemen strategis menekankan pada proses pengamatan dan evaluasi peluang serta ancaman lingkungan dengan melihat kekuatan dan kelemahan perusahaan atau organisasi. Manajemen strategis terdiri dari proses pengamatan atau analisis lingkungan serta perumusan strategi (Formulasi), implementasi strategi, dan evaluasi serta pengendalian (Wheelen, 2003: 4).

\section{Analisis Lingkungan Strategi Mandiri Amal Insani, Pendayagunaan Zakat Infak Dan Shadaqah Dalam Pengentasan Kemiskinan}

Tahap pertama dalam model manajemen strategis yaitu analisis lingkungan atau proses pemindaian secara internal dan eksternal (Wheelen, 2003: 4), meskipun definisi manajemen strategis adanya perbedaan dengan Wheelen, Robinson berpendapat manajemen strategis merupakan bagian satu paket atau set keputusan dan tindakan yang akan menghasilkan formulasi dan implementasi rencana yang dirancang untuk meraih tujuan organisasi. Dalam teorinya dia tidak mencantumkan proses analisis lingkungan sebagai proses. Sedangkan Agustinus pun berpendapat serupa bahwa proses strategis itu ada tiga yaitu, formulasi, implementasi, dan evaluasi.

Adapun Analisis Internal dan Eksternal Mandiri Amal Insani Foundation Region VI Jawa Barat, serta kekuatan, kelemahan, tantangan dan peluang Mandiri Amal Insani Foundation Region VI Jawa Barat. Proses analisis lingkungan internal dilakukan dengan rinci sekali dan detail di mana salah satu kekuatan MAI nama besar Bank Mandiri yang merupakan history MAI Foundation, kebijakan MAI Foundation menggarap pasar internal dan eksternal/nasabah, LAZNAS pertama corporate BUMN, serta memiliki donatur tetap yaitu Mandirian. Inilah kelebihan MAI, lembaga ini memiliki kolam ZIS yang jelas dan tersistematis dampaknya mereka tinggal fokus pada pendayagunaannya. Adapun hambatan yang ada di MAI yaitu, kompetensi dan kapasitas SDM yang belum merata, Pengelolaan keuangan belum tertata dengan baik, Dalam hal fundraising belum sepenuhnya dapat ekspansi ke masyarakat umum (lebih luas). Kekurangan (hambatan) internal lembaga ini memang belum memadainya SDM dan sistem pengelolaan zakat yang belum merata, ini 
Manajemen Strategis Pendayagunaan Zakat Infak dan Shadaqah dalam Pengentasan Kemiskinan dikarenakan usia MAI baru berdiri kurang lebih lima tahun berjalan serta masih melihat LAZ atau yayasan lain yang mengelola dana ZIS secara lebih profesional.

Berikut merupakan Analisis Internal yaitu, Kekuatan (Strenght) berupa, Nama besar Bank Mandiri yang merupakan history MAI Foundation, Memiliki dukungan Payroll zakat sistem dari salah satu instansi (Bank Mandiri),Kebijakan MAI Foundation menggarap pasar internal dan eksternal/nasabah, LAZNAS pertama coorporate BUMN, Memiliki donatur tetap yaitu Mandirian, Kepercayaan masyarakat terhadap MAI Foundation dalam perubahan pengelolaan menjadi profesional. Sedangkan Hambatan (Weakness), Keterbatasan dana operasional untuk kampanye zakat, Belum memadainya perangkat organisasi (kelengkapan struktur organisasi, kebijakan, SOP dan lain-lain), Kompetensi dan kapasitas SDM yang belum merata, Pengelolaan keuangan belum tertata dengan baik, Strategi komunikasi dan marketing belum tertata dengan baik, Belum seluruh bidang membuat perencanaan kerja dan pelaporan berkala, Kualitas pelayanan masih kurang, Kemampuan leadership belum merata, Masih kurangnya pemahaman visi MAI Foundation dan stakeholder internal, Dalam hal fundraising belum sepenuhnya dapat ekspansi ke masyarakat umum (lebih luas), Legalitas masih tarik-menarik (belum selesai).

Selanjutnya, analisis eksternal yang di mana terdapat peluang, dan ancaman. Peluang yang dimiliki oleh MAI yaitu, besarnya peluang pasar dari kalangan internal induk dan anak perusahaan maupun customernya, adanya himbauan direksi serta dukungan HC untuk menyalurkan dan ZISWAF melalui MAI Foundation. Peluang yang ada ini menjadi kesempatan emas bagi MAI untuk meningkatkan kinerjanya karena dukungan dari internal mandiri cukup antusias menyambut MAI ini, serta kebijakan-kebijakan yang mendorong agar para Mandirian berzakat, infaq, dan shadaqoh di lembaga ini. Analisis Eksternal Peluang (Opportunities), Pangsa pasar dan potensi ZISWAF yang sangat luas, Besarnya peluang pasar dari kalangan internal induk dan anak perusahaan maupun customernya, Adanya himbauan direksi serta dukungan HC untuk menyalurkan dan ZISWAF melalui MAI Foundation, Tumbuhnya kesadaran dan kepedulian sosial masyarakat baik internal maupun eksternal, Ancaman (Threath), Banyaknya grup kerja yang mendirikan komunitas kepedulian tersendiri dalam pengelolaan dana zakat ataupun sosial, Kebijakan pemerintah/BAZNAS yang melakukan intervensi atas aktivitas penghimpunan dan penyaluran, Persepsi masyarakat yang menganggap MAI Foundation terlalu eksklusif karyawan Bank Mandiri, Belum meratanya pemahaman mitra perusahaan terhadap pola kemitraam pelaksanaan program ZISWAF yang seharusnya dibangun.

Terakhir adalah ancaman, di mana MAI memiliki threath yang cukup menantang yaitu: (1) Banyaknya grup kerja yang mendirikan komunitas kepedulian tersendiri dalam pengelolaan dana zakat ataupun sosial, (2) Kebijakan pemerintah/BAZNAS yang melakukan intervensi atas aktivitas penghimpunan 
dan penyaluran, (3) Serta masyarakat yang menganggap MAI Foundation terlalu eksklusif karyawan Bank Mandiri.

\section{Formulasi Strategi Mandiri Amal Insani, Pendayagunaan Zakat Infak Dan Shadaqah Dalam Pengentasan Kemiskinan}

Formulasi strategi merupakan perencanaan jangka panjang yang berkaitan dengan pengembangan misi, tujuan, strategi dan kebijakan perusahaan atau organisasi. Formulasi strategi dimulai dengan kegiatan analisis situasional (situasional analysis) merupakan suatu proses untuk menemukan kecocokan strategis (strategic fit) antara peluang yang ada dilingkungan eksternal perusahaan dengan kekuatan internal yang dimiliki perusahaan pada saat yang sama memperhitungkan berbagai ancaman yang ada dilingkungan luar perusahaan dan kelemahan internal perusahaan (Solihin, 2012: 164).

Perumusan strategi seringkali ditunjukan sebagai perencanaan strategis atau jangka panjang, proses perumusan berurusan dengan pengembangan misi, tujuan strategi dan kebijakan perusahaan (Wheelen, 2003: 192).

Formulasi strategik akan dimulai dari perumusan misi dan tujuan organisasi, serta bagaimana lingkungan organisasi baik eksternal maupun internal yang akan mempengaruhi terhadap perumusan serta perkembangan misi dan tujuan organisasi serta bagaimana organisasi melakukan analisis terhadap lingkungan eksternal dan internal dalam suatu organisasi.

Tahap kedua menurut model dari manajemen strategik yaitu formulasi strategi dengan melakukan perumusan visi, yaitu "Menjadi Lembaga Zakat yang terpercaya, modern, dan Rahmatan Lil'alamin”. Serta misinya yaitu "Meningkatkan taraf hidup masyarakat, khususnya kaum dhuafa melalui program sosial, kemanusiaan, dan keagamaan dengan harapan yang dahulunya Mustahik menjadi muzakki, dan Memfasilitasi dan mengkoordinir penghimpunan dan penyaluran zakat, Infaq, Shadaqoh dan wakaf serta sumbangan lainnya yang tidak mengikat dari dan bagi masyarakat dalam rangka menunaikan kewajiban masing-masing dalam berzakat, infaq, shodaqoh, dan wakaf'.

Dari visi dan misi tersebut menghasilkan satu tujuan dari Mandiri Amal Insani Foundation Region VI Jawa Barat yaitu untuk mempertahankan dan memelihara kekuatan, serta memperbaiki kelemahan-kelemahan yang menjadi hambatan dan tantangan yang memelihara margin pendapatan untuk tumbuh terus berkelanjutan (Sustainable growth) dan untuk peningkatan kualitas pelayanan terhadap mustahik, muzakki, dan pemangku kepentingan lainnya serta Menumbuhkan kepemilikan aset melalui pengelolaan program (Intensifikasi Program) serta menumbuh kembangkan semangat inklusifitas dan altruisme.

Tujuan dari Mandiri Amal Insani Foundation yaitu sebagai berikut: (1) Meningkatkan kesadaran masyarakat untuk menjalankan ZISWAF Ekspansi Pasar, (2) Meningkatkan kualitas dan akses masyarakat terhadap program 
Manajemen Strategis Pendayagunaan Zakat Infak dan Shadaqah dalam Pengentasan Kemiskinan pelayanan, (3) Advokasi dan pemberdayaan, (4) Terwujudnya penguatan kelembagaan dengan tata kelola organisasi berstandar nasional (LAZNAS INSTITUTIONAL BUILDING), (5) Menguatkan volunterisme dan kewirausahaan sosial di masyarakat, (6) Terwujudnya kemandirian organisasi melalui intensifikasi, (7) Ekstensifikasi \& diversifikasi sumber daya organisasi, (8) Menumbuhkan kepemilikan aset melalui pengelolaan program (Intensifikasi Program). Adapun tujuan-tujuan lain dari Sustainable Development Goals (SDGs) sebagai bagian tanggung jawab MAI dalam berkontribusi permasalahanpermasalahan yang ada. Terdapat 17 tujuan yang ingin dicapai oleh MAI, yaitu: (1) Tanpa kemiskinan, (2) Tanpa kelaparan, (3) Kesehatan yang baik dan kesejahteraan, (4) Pendidikan berkualitas kesetaraan gender, (5) Air bersih dan sanitasi, (6) Energi bersih dan terjangkau, (7) Pertumbuhan ekonomi dan pekerjaan layak, (8) Industri, inovasi, dan infrastruktur, (9) Mengurangi kesenjangan, (10) Keberlanjutan kota dan komunitas, (11) Konsumsi dan produksi bertanggung jawab, (12) Aksi terhadap iklim, (13) Kehidupan bawah laut, (14) Kehidupan di darat, (15) Intitusi peradilan yang kuat dan kedamaian, (16) Kemitraan untuk mencapai tujuan.

Sehingga Mandiri Amal Insani Foundation Region VI Jawa Barat mampu menghimpun, dan mendistribusikan zakat lebih banyak dan lebih luas lagi untuk mendistribusikan zakatnya. Dan bukan hanya luas namun, produktivitas yang diutamakan oleh MAI dalam proses menjalankan program-program yang ada. Keuntungan yang dimiliki Mandiri Amal Insani Foundation Region VI Jawa Barat yaitu kantor yang berada di Jalan Soekarno Hatta No.486 Batununggal Bandung Kidul Bandung serta data yang mendukung dan dilihat dari Sumber daya manusia yang memadai meskipun secara jumlah tidak sebanyak cabang yang lain.

Pada akhirnya proses analisis SWOT menghasilkan strategi yang pada tahap awal sudah dilakukan analisis lingkungan, maka solusi dari empat bagian itu yaitu: (1) Strategi S-O, di mana MAI menciptakan program yang inovatif dan sustain sesuai kebutuhan penerima manfaat. Ini akan menjadikan MAI lebih produktif dalam memberikan manfaat terhadap mustahik karena didukung oleh internal yang kuat dan peluang yang cukup besar, (2) Strategi S-T, berarti Mandiri Amal Insani harus meningkatkan layanan aktif dengan memanfaatkan relawan yang tersebar di Jawa Barat dan partner relasi sesama lembaga zakat agar cepat tanggap dalam memberikan bantuan, karena ancaman yang ada dapat mengganggu dan dengan memanfaatkan kekuatan yang ada agar stretgi S-T ini dapat goal, (3) Strategi W-O, di mana strategi ini menggunakan peluang untuk menyelesaikan kelemahan. MAI mengambil solusi sosialisasi rutin tentang program yang sustain dan juga pendampingan untuk setiap program yang kemudian nantinya agar peluang internal MAI dapat dimanfaatkan serta mengurangi kekurangan yang ada di Mandiri Amal Insani, (4) Strategi W-T, di 
mana MAI mengambil jalan menghentikan program yang tidak multiplier effect dan memberhentikan SDM yang kapasitasnya tidak memadai dan tidak bisa ditingkatkan serta mengganggu keberlangsungan organisasi. Yang diharapkan dengan solusi tersebut, lembaga ini dapat menyelasaikan masalahnya secara efektif dan efisien.

Adapun kebijakan MAI Foundation terbagi menjadi beberapa bagian, yaitu: umum, khusus, kebijakan dana zakat, dan infak shadaqah serta kebijakan dana terkait. Untuk kebijakan umum terdapat Penyusunan proses Rencana Kerja serta Anggaran Tahunan (RKAT) yang di mana periode 2019 ini disusun dengan wajar, realistis, sejalan dengan tujuan lembaga. Sedangkan kebijakan khususnya yaitu ada dalam penyusunan anggaran, di mana rencana kerja disusun merupakan acuan bagi pelaksanaan kegiatan dalam rangka mencapai tujuan lembaga sesuai dengan Renstra yang telah ditetapkan. Kebijakan dana zakat, sumber dana zakat berasal dari, penerimaan dana masyarakat, bagi hasil dari dana zakat, pengembalian dana bergulir/investasi yang diambilkan dari dana zakat, penjualana aset-aset yang pada mulanya dibeli menggunakan dana zakat. Kebijakan dana infak, peruntukan dana infak pada tahun 2019, yaitu: Divisi program untuk penyaluran program insidental beserta biaya operasionalnya berdasarkan permintaan dari donatur ataupun ajuan masyarakat yag telah diverifikasi dan program-program yag menerima manfaatnya tidak memenuhi kriteria dana infak. Divisi program untuk mencairkan dana-dana terkait (infak tematik) yang diperoleh divisi Fundrising, 20\% alokasi dari infak untuk dana amil.

Kebijakan Dana Terkait, Penyaluran dana terkait seperti zakat Muqoyyad, infak tematik ataupun infak kemanusiaan dikeluarkan sesuai peruntukannya. Atas saldo dana terkait yang telah selesai penyaluran dana programnya, maka akan dibuatkan berita acara pengalokasian saldo tersebut.

Kebijakan dana zakat, infak, dan shadaqah berupa sumber dana zakat berasal dari proses penerimaan dana sosial masyarakat, dan peruntukannya bagi divisi program untuk penyaluran program rutin maupun insidental beserta biaya operasionalnya berdasarkan ajuan cabang/mitra ataupun ajuan masyarakat yang telah diverifikasi baik dalam maupun luar negeri. Sedangkan kebijakan dana infak dan shadaqah dalam peruntukannya pada divisi program untuk penyaluran program insidental beserta biaya operasionalnya berdasarkan permintaan dari donatur ataupun ajuan masyarakat yang telah diverifikasi dan program-program yang menerima manfaatnya tidak memenuhi kriteria dana infak. Dan untuk kebijakan dana terkait yaitu penyaluran dana terkait seperti zakat Muqoyyad, infak tematik ataupun infak kemanusiaan dikeluarkan sesuai peruntukannya. Kebijakan-kebijakan tersebut merupakan kebijakan yang dibuat oleh MAI pusat yang diperuntukan kepada seluruh kanwil-kanwil yang ada di seluruh Indonesia, serta diharapkan dapat mempermudah dalam menjalankan program-program yang ada. 
Manajemen Strategis Pendayagunaan Zakat Infak dan Shadaqah dalam Pengentasan Kemiskinan

\section{Implementasi Strategi Mandiri Amal Insani, Pendayagunaan Zakat Infak Dan Shadaqah Dalam Pengentasan Kemiskinan}

Tahap ketiga dari Manajemen Strategis yaitu Implementasi yang berisi tentang penerapan program, anggaran dan prosedur. Sesuai dengan teori Popy Rufaidah dalam buku Manajemen Strategik dan dalam model manajemen startegis Wheleen dan Hunger. Program yang dimiliki oleh Mandiri Amal Insani Foundation Region VI Jawa Barat. Program yang ada yaitu Bina Ekonomi, Bina Kesehatan, Bina Ilmu, Bina Fisik dan Bina Sosial sudah berjalan dengan baik. Untuk Anggaran yang digunakan oleh Mandiri Amal Insani Foundation sudah bisa dikatakan sudah tepat guna karena pada dasarnya anggaran itu akan berbeda-beda disetiap program yang akan diimplementasikannya tergantung dari programnya tersebut apabila programnya besar maka akan membutuhkan anggaran yang besar juga dan pasti akan menghasilkan manfaat yang besar pula (Wheelen, 2003: 4).

Penerapan strategi sering kali disebut "tahap aksi" dari manajemen strategis. Menerapkan strategi berarti memobilisasi karyawan dan manajer untuk melaksanakan strategi yang telah dirumuskan. Seringkali dianggap sebagai tahap yang paling sulit dalam manajemen strategis, penerapan atau implementasi strategi membutuhkan disiplin, komitmen, dan pengorbanan personal. Penerapan strategi yang berhasil bergantung pada kemampuan manajer untuk memotivasi karyawan,yang lebih merupakan seni dari pada pengetahuan. Strategi tersebut dirumuskan, namun bila tidak diterapkan tidak ada gunanya.

Implementasi yaitu meletakan strategi menjadi sebuah kegiatan yang mana kegiatan itu tidak terlepas dari program-program yang sudah direncanakan, setelah selasai membuat program maka sebuah organisasi maupun lembaga harus menyiapkan anggaran atau dana untuk menajdi penunjang terlaksananya program-program yang telah direncanakan. Adapun prosedur merupakan urutan -urutan aktivitas yang harus diselesaikan untuk pekerjaan dalam program, dengan adanya prosedur sebuah pekerjaan dapat diselesaikan dengan baik, sehingga bisa mencapai sebuah tujuan organisai tersebut.

Aktivitas yang kedua yaitu meliputi aspek-aspek kepemimpinan efektif berikut pengambilan keputusan, kewenagan dan tanggung jawabnya serta budaya organisasi. Aktivitas-aktivitas tersebut menjadi penting kaitannya dengan pembuatan prosedur dan program.

Adapun visi MAI yaitu Menjadi lembaga zakat yang terpercaya, modern, dan rahmatan lil'alamin, sedangkan misi yaitu Memfasilitasi dan mengkoordinir penghimpunan dan penyaluran zakat, infaq, shadaqoh dan wakaf serta sumbangan lainnya yang tidak mengikat dari dan bagi masyarakat dalam rangka menunaikan kewajiban masing-masing dalam berzakat, infaq, shodaqoh, dan wakaf. Meningkatkan taraf hidup masyarakat, khususnya kaum dhuafa melalui 
program sosial, kemanusiaan, dan keagamaan dengan harapan yang dahulunya mustahik menjadi muzakki. Meningkatkan kemandirian Independensi \& Akuntabilitas lembaga dalam pengelolaan sumber daya dan Mentransformasikan nilai-nilai untuk mewujudkan masyarakat religius.

Mandiri Amal Insani Foundation Region VI Jawa Barat memiliki beberapa program kerja yang diklasifikasikan menjadi 5 program besar yang dimana program tersebut diklasifikasikan berdasarkan jenisnya yang dinamakan dengan nama "bina", yang diharapkan dengan semangat membina ini program-program yang ada tidak hanya program yang bersifat konsumtif tapi juga bersifat sustain, berkelanjutan serta bersifat memberdayakan. Program kerja tersebut merupakan turunan dari MAI Foundation pusat yang berarti MAI Region VI masih menginduk secara garis besar dengan MAI pusat. Namun tidak semua program sama dengan pusat, ada beberapa program yang berjalan secara mandiri tanpa intervensi dari MAI pusat, program kerja tersebut menjadi inisiatif para pengurus dan pelaksana MAI Region VI yang nantinya menjadi program khusus atau khas dari Region VI. Selain kelima program bina, terdapat pula program pendukung yang menjadi rutinitas MAI Foundation yaitu program Ramadhan, Qurban, dan lain-lain. Program-program tersebut menjadi program berdasarkan waktu yang dimana penerapan dana pun disesuaikan dengan program yang sejenis.

Program-program pendayagunaan (Bussiness Proces) penyaluran yaitu diantaranya Bina Ekonomi, Bina Sosial, Bina Kesehatan, Bina Fisik, dan Bina Ilmu. Masing-masing bina memiliki perbedaan dan karakteristik masing-masing. yaitu: Bina Ekonomi, Bina Ekonomi merupakan program kerja yang diklasifikasikan berdasarkan segala sesuatu yang memiliki karakteristik ekonomi. Seluruh program-program yang termasuk kelompok Bina Ekonomi akan diproyeksikan kepada pemberdayaan yang bersifat berkelanjutan (Sustain of Program) yang dimana setiap mustahik yang mendapatkan bantuan dari MAI akan menjadi mustahik yang harus bertransformasi dari mustahik menjadi muzakki. Program yang berfokus pada sektor ekonomi, dengan memberikan pendampingan yang pada akhirnya program ini memiliki tujuan utama yaitu mengubah status dhuafa yang sebelumnya adalah penerima manfaat menjadi donatur.

\section{STRATEGI}

BINA EKONOMI

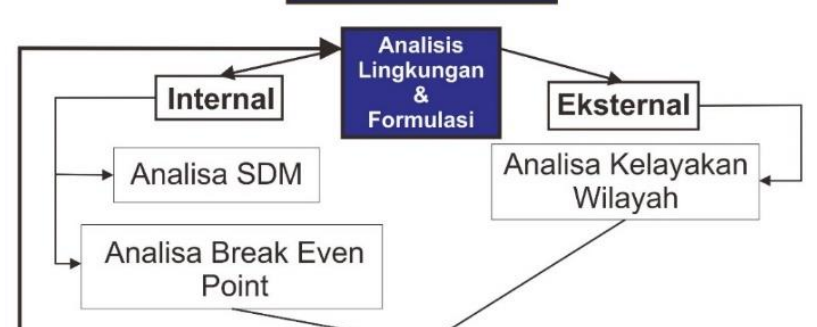


Sumber: Hasil analisis peneliti dari hasil wawancara dengan bagian program

Gambar 2. Strategi Bina Ekonomi dalam Usaha Produktif

Program Aktif, Program Usaha Bakter Farm, Program ini merupakan program sustain yang berlokasi di Jl. Bojonggaling-Sasagaran Kp. Cikaret Hilir Rt 01/02 Desa sasagaran Kec. Kebonpedes Kab. Sukabumi, yang dimana usaha ini di prakarsai oleh pak Ujang (Kelompok budidaya ikan (piokdakan). Sekelompok komunitas yang pada awalnya sudah mempunyai kolam lele namun belum bisa mengadakan bibit sendiri yang masih membeli bibit serta belum memiliki bioflok. MAI membantu dari tahapan awal mulai dari proses pengajuan sampai pengadaan bioflok sebanyak 7 buah. Hasil yang diperoleh setelah pengembangan berjalan sesuai dengan rencana, usaha lele ini dapat mandiri dengan bantuan bioflok menjadi berdaya dan mandiri tanpa harus membeli.

Bina Ilmu merupakan program kerja yang diklasifikasikan berdasarkan segala sesuatu yang memiliki karakteristik keilmuan atau pendidikan. Seluruh program-program yang termasuk kepada kelompok Bina Ilmu dari mustahik yang mendapatkan bantuan dari MAI diharapkan terbantu dalam hal pendidikan lanjut atau bantuan langsung jika tersendat dalam hal biaya pendidikan. Program yang memiliki fokus utama dalam bidang pendidikan. Karena menjadi orang berilmu merupakan salah satu hal penting dalam kehidupan. Program kerja Bina Ilmu dibagi lagi menjadi dua program berdasarkan aktif dan pasif serta strategi 
atau sistem yang digunakan MAI Foundation. Program-program serta strategi Bina Ilmu yaitu diantaranya: Program Aktif Beasiswa Bintang Mandiri, Program ini merupakan program beasiswa yang dimana bersifat memberdayakan dan mendidik, karena program ini terintegrasi juga dengan program lain yaitu program Learning Camp. Beasiswa ini memberikan bantuan sebanyak 608 anak Beasiswa Anak Asuh, Ustadz sebanyak 196 dan operasional yayasan (15 lembaga sosial) serta ratusan mahasiswa siswa yang mendapatkan beasiswa ini. Fokusnya masih pada siswa maksimal duduk di SLTA, sedangkan tingkat perguruan tinggi masih terbatas.

Learning Camp, Learning Camp merupakan program pelatihan atau training yang dimana diperuntukan bagi para siswa SLTA dan mengikuti serangkaian seleksi. Kegiatan pelatihan ini dilakukan selama 40 hari dengan rangkaian acara pendidikan yang padat akan ilmu pengetahuan untuk persiapan masuk perguruan tinggi serta rangkaian pembinaan spiritual. Pada tahun 2018 bekerjasama dengan Salman ITB berhasil menyeleksi sebanyak 60 siswa. Rata-rata siswa yang lolos masuk PTN atau PTS sekitar 75-85 \% ketercapaian dari total 60 siswa. Sebagaimana pernyataan oleh Ibu Wadifah bagian pembina LC MAI :

"Alhamdulillah setiap tahunnya dari awal berjalan LC selalu meloloskan siswa-siswanya sampai masuk PTN atau PTS favorit dengan nilai yang memuaskan meskipun mereka bukan tergolong orang-orang mampu dalam segi finansial. Dari awal mereka memang sudah tergolong mustahik fisabilillah dan bahkan miskin, namun tidak menghalangi mereka untuk meraih cita-citanya" (Hasil wawancara dengan Ibu Wadifah, pada tanggal 10 Mei 2019).

Bina Kesehatan, Bina Kesehatan merupakan program kerja yang diklasifikasikan berdasarkan segala sesuatu yang memiliki karakteristik medis atau kesehatan. Seluruh program-program yang termasuk kepada kelompok Bina Kesehatan dari mustahik yang mendapatkan bantuan dari MAI diharapkan terbantu dalam hal kesehatan. Program yang berfokus pada sektor kesehatan. Dimana MAI memperhatikan keadaan dan kesehatan penerima manfaat di Indonesia khususnya dhuafa, yang mana banyak dari mereka belum dapat merasakan fasilitas kesehatan yang layak. Program kerja Bina Kesehatan dibagi lagi menjadi dua program berdasarkan aktif dan pasif serta strategi atau sistem yang digunakan MAI Foundation. Program-program serta strategi Bina Kesehatan yaitu:

Program Aktif, Program RSM (Rumah Singgah Mandiri) Program ini adalah semacam Shelter yang diperuntukan untuk masyarakat di luar kota Bandung dan Jawa Barat yang tergolong fakir miskin yang sedang melakukan berobat jalan hanya di Rumah Sakit Hasan Sadikin (RSHS) dengan kriteria pasien harus memiliki BPJS kelas 3. Program Rumah Singgah Mandiri ini bukan perpanjangan RSHS yang dimana ada proses tindakan medis, di luar RSHS 
Manajemen Strategis Pendayagunaan Zakat Infak dan Shadaqah dalam Pengentasan Kemiskinan dilarang adanya tindakan medis. Dengan kata lain Program ini merupakan turunan dari program kerja bina kesehatan dan termasuk program aktif. Rumah Singgah Mandiri adalah program MAI Foundation yang berlokasi di dekat Rumah Sakit Hasan Sadikin (RSHS), yang dimana RSM ini menjadi tempat singgah para pasien Rumah Sakit Hasan Sadikin yang harus melakukan cek up dan rawat jalan, para pasien yang kurang mampu diberikan bantuan dan kemudahan agar biaya inap diluar rumah sakit dapat terbantu, jika mereka mengandalkan tempat tinggal yang berbayar maka dengan adanya RSM ini para pasien tersebut bisa terbantu dan mengurangi pengeluaran atau biaya hidup selama berobat di RSHS. Program launching di Rumah Sakit Hasan Sadikin (RSHS) Jawa Barat (2 tahun) sejak teh Maya ada di MAI. Dana yang digunakan adalah dana infak dari MAI pusat.

Bina Sosial, Bina Kesehatan merupakan program kerja yang diklasifikasikan berdasarkan segala sesuatu yang memiliki karakteristik berkaitan dengan sosial. Seluruh program-program yang termasuk kepada kelompok Bina Sosial dari mustahik yang mendapatkan bantuan dari MAI diharapkan terbantu dalam hal sosial, bantuan-bantuan, donasi, bencana alam dan lain-lain. Program yang memiliki tujuan untuk membantu meringankan beban penerima manfaat. Program kerja Bina Sosial hanya memiliki program pasif dikarenakan program kerja ini sampai hari ini masih mencari model program yang akan menjadi program aktif dan sustain. Berikut ini daftar program pasif serta sistem yang dipakai. Program ini notabene bersifat pasif karena hanya menerima ajuan yang bersifat konsumtif yang tidak berorientasi dalam proses pendayagunaan.

Bina Fisik, Bina Fisik merupakan program kerja yang diklasifikasikan berdasarkan segala sesuatu yang memiliki karakteristik berkaitan dengan fisik dalam artian program bantuan pembangunan sebuah gedung, rumah, atau sarana prasarana. Program yang bertujuan untuk membangun maupun memperbaiki sarana fisik, baik rumah ibadah, sekolah, rumah, maupun sarana publik dan tempat tersebut banyak digunakan oleh kaum dhuafa. Program kerja Bina Sosial hanya memiliki program pasif dikarenakan program kerja ini sampai hari ini masih mencari model program yang akan menjadi program aktif dan sustain. Serta ajuan-ajuan yang ada lebih bersifat konsumtif. Berikut ini daftar program pasif serta sistem yang dipakai. Program ini notabene bersifat pasif karena hanya menerima ajuan yang bersifat konsumtif yang tidak berorientasi dalam proses pendayagunaan, seperti Renovasi madrasah, pesantren Binaan Al-Muhajirin mendapat bantuan sebesar 25 juta untuk biaya renovasi madrasah, Al-khairiyah, serta bantuan air di pondok dan untuk masyarakat.

Prioritas prosedur dalam perencanaan dari kelima program kerja difokuskan berdasarkan program perbina, dimana fokus utama yang sedang digarap oleh MAI yaitu dalam hal ekonomi produktif dan pendidikan dal hal ini bina ilmu. 
A. R. Alam, S. Anwar, A. I. Setiawan

\section{Evaluasi dan Pengendalian Strategi Mandiri Amal Insani, Pendayagunaan Zakat Infak Dan Shadaqah Dalam Pengentasan Kemiskinan}

Tahapan terakhir dari Manajemen Strategik yaitu evaluasi dan pengendalian (Proses Evaluasi Manajemen Strategik Mandiri Amal Insani Foundation Region VI Jawa Barat terlebih dahulu menyerap aspirasi mustahik, serta evaluasi internal guna untuk menjadi bahan evaluasi dan menciptakan inovasi terbaru, evaluasi yang dilakukan oleh Mandiri Amal Insani Foundation Region VI Jawa Barat dalam waktu 6 bulan sekali (persemester) yang terbagi menjadi dua horizon waktu perencanaan strategis, yaitu program strategis jangka panjang lima tahunan serta jangka pendek sekitar satu tahun. Evaluasi merupakan tahapan yang terakhir dari seluruh rangkaian kegiatan yang terdapat pada organisasi serta proses mendapatkan informasi mengenai pelaksanaan sebuah perencanaan bisnis dan kinerjanya serta menjadi tahap perbandingan informasi suatu kegiatan atau program dengan standar yang telah ditentukan (Wheelen, 2003: 4).

Evaluasi Strategik adalah suatu proses mendapatkan informasi mengenai pelaksanaan rencana-rencana bisnis dan kinerjanya serta membandingkan informasi tersebut dengan standar yang telah ditentukan.

Proses evaluasi dan control strategi dimulai dari menentukan apa yang harus diukur, menetapkan standar kinerja, melakukan pengukuran, dan apabila tidak sesuai dengan harapan maka harus dilakukan tindakan mengoreksi (Siagian, 2008: 15).

Proses evaluasi serta kontrol strategi dimulai dari menentukan apa yang akan diukur, menetapkan standar kinerja, melakukan pengukuran, dan apabila adanya ketidaksesuaian dengan harapan maka harus dilakukan tindakan yang tepat agar tujuan awal yang telah direncanakan sesuai dengan prosedur agar akhir suatu program melahirkan hasil yang diharapkan. Evaluasi yang dilakukan oleh MAI Foundation Region VI dengan melakukan sebuah evalusi berkala. Evaluasi persemester, evaluasi program-program dari kelima bina, serta evaluasi dengan cara mendengarkan masukan, komentar dari para mustahik terkait program yang pernah mereka dapatkan.

Evaluasi yang dilakukan oleh MAI Foundation Region VI dengan melakukan sebuah evalusi berkala. Evaluasi persemester, evaluasi programprogram dari kelima bina, serta evaluasi dengan cara mendengarkan masukan, komentar dari para mustahik terkait program yang pernah mereka dapatkan. Pertama, Evaluasi Per-Semester (Evalusai Internal), Proses evaluasi ini dilakukan oleh MAI pusat dengan kanwil terkait. Evaluasi yang dilakukan berdasarkan waktu dengan teknik semester ini dirasa lebih efektif agar program jangka pendek, menengah, dan jangka panjang bisa sesuai dengan perencanaan awal dan prosedur yang ada. 
Manajemen Strategis Pendayagunaan Zakat Infak dan Shadaqah dalam Pengentasan Kemiskinan

Evaluasi dari mustahik Pak Iwan (tukang parkir di kanwil Mandiri Region VI) sebagai penerima manfaat program bantuan THR Outsourcing (tukang parkir Region VI) berkata bahwa: "Saya berharap MAI Region VI lebih baik lagi, dan menurut pendapat saya sudah bagus program THR untuk saya dan temanteman saya yang menjadi satpam, cleaning service, tukang parkir, dan lain-lain (Hasil wawacara dengan Pak Iwan, dilaksanakan pada 7 Agustus 2019).

Bapak Deni Ahmad Patoni sebagai pengasuh pondok pesantren AlMuhajirin yang beralamat tepatnya di Kampung. Cijambu Rt 01 Rw 09 desa/kec. Selaawi Garut. Beliau termasuk kepada segmen bina fisik karena mendapatkan dana bantuan untuk renovasi pesantren dan madrasahnya. Dimana beliau menyatakan:

"Kami bangga bisa kenal dan dipertemukan dengan MAI. Menurut kami MAI salah satu yayasan terbaik yang banyak sekali menebar manfaat dan kami pesantren Al Muhajirin yang sudah merasakan begitu sentral dan begitu menebar berbagai kebaikan, pokoknya menurut saya MAI jempol. Semoga tambah berkah" (Hasil wawancara dengan Bapak Deni pada tanggal 20 Juli 2019).

Perbandingan kinerja tahun 2018 dengan tahun 2017 merupakan bukti bahwa MAI dikelola secara profesional karena dengan adanya evaluasi secara berkala, akan memberikan dampak positif bagi perkembangan lembaga itu sendiri.

Hasil evaluasi akan dijadikan dasar bagi organisasi dalam melakukan pengendalian yakni apakah kesenjangan yang terjadi antara kinerja aktual dengan kinerja standar masih berada dalam toleransi atau kah perbadaan antara kinerja aktual dengan kinerja standar sudah menyimpang sangat jauh sehingga perlu dilakukan tindak koreksi (corrective action). Hasil evaluasi dan pengendalian selanjutnya akan menjadi umpan balik (feed back) bagi organisasi yang memungkinkan sebuah organisasi melakukan perbaikan dalam setiap langkah proses manajemen strategik sejak pemindaian lingkungan sampai pada tahap evaluasi dan pengendalian.

Kegiatan moneva dan kontrol di lapangan terkait program-program yang ada secara intens dilakukan. Hampir seluruh program bina yang lima, seluruhnya menggunakan sistem survei dan cek kontrol. Semua di data dengan rinci dan detail. Bagian divisi program ibu Maya menuturkan bahwa:

"Seluruh program di MAI di proyeksikan pada arah produktif. Karena mengatasi kemiskinan khususnya tidak hanya dengan memberi donasi pasif secara terus menerus, namun harus kita bantu edukasi juga dan bantu ubah mind set agar mereka para mustahik bisa berusaha untuk bertransformasi dari mustahik menjadi muzakki."

Dengan demikian, dari keempat proses manajemen strategi yang terintegrasi dengan proses pendayagunaan dana zakat, infak, dan shadaqoh 
dalam upaya pengentasan kemiskinan. Program dari kelima bina dapat dikatakan ikut andil besar dalam upaya pengentasan kemiskinan karena program-program yang ada fokus pada pendayaguaan produktif meskipun memang masih lebih banyak pasif daripada aktif, namun MAI berusaha dengan kekuatan, dan peluang yang ada sehingga kelemahan dan ancaman dapat diminimalisir.

\section{PENUTUP}

Berdasarkan uraian teori Manajemen Strategis serta hasil penelitian yang telah dilakukan di Mandiri Amal Insani Foundation Region VI Jawa Barat. Peneliti menemukan serangkaian indikator atau tahapan dalam Manajemen Strategis, yaitu Environmental Scanning (Analisis Strategi), Strategy Formulation (Formulasi Strategi), Strategy Implementation (Implementasi Strategi) dan Evaluation and Control (Evaluasi dan Pengendalian), yang sudah dilakukan dengan baik dan sistematis.

Tahapan yang pertama dalam Manajemen Strategis yaitu Analisis Lingkungan, berdasarkan pada analisis lingkungan baik yang bersifat internal maupun eksternal terdapat kekuatan (Strenght), kelemahan (Weakness) di lingkungan internal sedangkan tantangan (Threath) dan peluang (Opportunities) terdapat di lingkungan eksternal Mandiri Amal Insani Foundation Region VI Jawa Barat. Proses analisis lingkungan internal dilakukan dengan rinci sekali dan detail di mana salah satu kekuatan MAI nama besar Bank Mandiri yang merupakan bistory MAI Foundation, dan Kebijakan MAI Foundation menggarap pasar internal dan eksternal/nasabah. Adapun hambatan yang ada di MAI yaitu, kompetensi dan kapasitas SDM yang belum merata, masih kurangnya pemahaman visi MAI Foundation dan stakeholder internal, dan seluruh bidang membuat perencanaan kerja dan pelaporan berkala. Selanjutnya analisis lingkungan eksternal terdapat peluang, dan peluang yang dimiliki oleh MAI yaitu, besarnya peluang pasar dari kalangan internal induk dan anak perusahaan maupun customernya. Dan yang terakhir yaitu ancaman berupa kebijakan pemerintah/BAZNAS yang melakukan intervensi atas aktivitas penghimpunan dan penyaluran.

Tahapan kedua dalam Manajemen Strategis yaitu Formulasi Strategi Mandiri Amal Insani Foundation Region VI Jawa Barat, terdapat empat bagian di dalam proses formulasi ini yaitu: visi dan misi, tujuan, strategi, dan kebijakan. Dengan melakukan perumusan visi MAI Foundation yaitu "Menjadi Lembaga Zakat yang Terpercaya, Modern, dan Rahmatan Lil'alamin", dan misinya yaitu untuk "Meningkatkan taraf hidup masyarakat, khususnya kaum dhuafa melalui program sosial, kemanusiaan, dan keagamaan dengan harapan yang dahulunya mustahik menjadi muzakki", dan tujuan dari Mandiri Amal Insani Foundation yaitu "Meningkatkan kesadaran masyarakat untuk menjalankan ZISWAF (Ekspansi Pasar)". Adapun tujuan MAI yaitu meningkatkan dan memaksimalkan kualitas dan akses masyarakat terhadap program pelayanan, advokasi dan 
Manajemen Strategis Pendayagunaan Zakat Infak dan Shadaqah dalam Pengentasan Kemiskinan pemberdayaan serta terwujudnya masyarakat yang mandiri dalam kemandirian organisasi melalui intensifikasi, ekstensifikasi dan diversifikasi sumber daya organisasi. Sedangkan strategi yang dimiliki MAI yaitu: strategi S-O, strategi S-T, strategi W-O, strategi W-T yang dimana pada intinya bertujuan untuk mempertahankan dan memelihara kekuatan, serta memperbaiki kelemahankelemahan yang menjadi hambatan dan tantangan yang memelihara margin pendapatan untuk tumbuh terus berkelanjutan (Sustainable growth). Sedangkan kebijakan MAI dibagi menjadi dua bagian, yaitu kebijakan umum dan khusus.

Tahapan yang ketiga dalam manajemen strategik yaitu implementasi strategi yang terdapat didalamnya beberapa bagian yaitu: program, anggaran, dan prosedur. Mandiri Amal Insani, hal ini dilihat dengan adanya program yang dibagi menjadi lima kelompok bina berdasarkan sektor-sektor turunan SDGs yaitu Bina Ekonomi, Bina kesehatan, Bina Ilmu, Bina Fisik, serta Bina Sosial yang sudah mewakili tujuan-tujuan dari SDGs itu sendiri. Lima program bina tersebut sudah berjalan sesuai dengan prosedur yang ada di MAI. Sedangkan anggaran yang digunakan oleh Mandiri Amal Insani Foundation sudah bisa dikatakan sudah tepat guna karena pada dasarnya anggaran itu akan berbedabeda disetiap program yang akan diimplementasikannya tergantung dari programnya tersebut apabila programnya besar maka akan membutuhkan anggaran yang besar juga dan pasti akan menghasilkan manfaat yang besar pula.

Tahapan yang terakhir dari manajemen strategik yaitu Evaluasi Strategi Mandiri Amal Insani Region VI Jawa Barat sudah efektif, proses evaluasi yang dilakukan oleh Mandiri Amal Insani terlebih dahulu mendengarkan suara mustahik dari setiap sektor program bina yang ada guna menjadi bahan evaluasi dan menciptakan inovasi terbaru yang dilakukan 6 bulan sekali (1 semester) yang terbagi menjadi dua horizon waktu perencanaan strategis, yaitu program strategis jangka panjang lima tahun dan jangka pendek satu tahun. Adapun evaluasi untuk kinerja dan pembahasan anggaran dilakukan sebulan sekali dan dua bulan sekali untuk rapat kinerja.

Dengan demikian, dari keempat proses manajemen strategi. Dimulai dari proses analisis lingkungan internal dan eksternal, formulasi, implementasi, hingga evaluasi serta pengendalian terintegrasi dengan proses pendayagunaan dana zakat, infak, dan shadaqoh dalam upaya pengentasan kemiskinan telah berhasil dan sesuai dengan praktik dilapangan serta terintegrasinya satu program dengan program lain yang berdayaguna dalam upaya meminimalisir kemiskinan yang ada.

\section{DAFTAR PUSTAKA}

Anwar, S. (2016). Optimalisasi Pelayanan Zakat Melalui Pemberdayaan Networking Lembaga dalam Anida (Aktualisasi Nuansa Ilmu Dakwab), 15(2), 1410-5705. 
A. R. Alam, S. Anwar, A. I. Setiawan

Hafidhuddin, D. (2007). Zakat dalam Perekonomian Modern. Jakarta: Gema Insani. Hilman, A. (2016). Implementasi Manajemen Zakat Produktif dalam Upaya Mengentaskan Kemiskinan dalam Tadbir: Jurusan Manajemen Dakwah, 1(4), 338-354.

Latifah, E. (2017). Manajemen Strategik Rumah Amal Salman dalam Meningkatkean Fundraising Zakat. Skripsi, Jurusan Manajemen Dakwah, UIN Sunan Gunung Djati Bandung.

Qardhawy, Y. (1996) Hukum Zakat. Jakarta: PT. Pustaka Litera Antarnusa.

Rustanto, B. (2015). Menangani Kemiskinan. Bandung: PT. Remaja Rosdakarya.

Setiawan, A. I. (2012). Dakwah Berbasis Pemberdayaan Ekonomi dan Peningkatan Kesejahteraan Mad'u dalam Ilmu Dakwah: Academic Journal for Homiletic Studies, 6(2), 347-262.

Siagian, S. P. (2010). Manajemen Sumber Daya Manusia. Jakarta: Bumi Aksara.

Solihin, I. (2012). Manajemen Strategik. Jakarta: Erlangga

Wheelen, T. L., \& Hunger, J. D. (2003). Manajemen Strategis. Yogyakarta: Andi. 